\title{
Electronic Corporate Tax, Aggregate Federally Collected Tax Revenues and Economic Growth: A Multivariate VAR Approach
}

\author{
Okolo Ndu Marvis ${ }^{1, *}$, Ideh O. Abel ${ }^{1}$, Emengini Steve Emeka ${ }^{2}$ \\ ${ }^{1}$ Department of Accounting and Finance, Faculty of the Social Sciences, Delta State University, Abraka, Nigeria \\ ${ }^{2}$ Department of Accountancy, University of Nigeria, Nsukka, Nigeria
}

Received March 8, 2021; Revised May 26, 2021; Accepted June 6, 2021

\section{CiteThisPaperinthefollowingCitationStyles}

(a): [1] Okolo Ndu Marvis, Ideh O. Abel, Emengini Steve Emeka, "Electronic Corporate Tax, Aggregate Federally Collected Tax Revenues and Economic Growth: A Multivariate VAR Approach," Universal Journal of Accounting and Finance, Vol. 9, No. 3, pp. 372 - 382, 2021. DOI: 10.13189/ujaf.2021.090311.

(b): Okolo Ndu Marvis, Ideh O. Abel, Emengini Steve Emeka (2021). Electronic Corporate Tax, Aggregate Federally Collected Tax Revenues and Economic Growth: A Multivariate VAR Approach. Universal Journal of Accounting and Finance, 9(3), 372 - 382. DOI: 10.13189/ujaf.2021.090311.

Copyright $(2021$ by authors, all rights reserved. Authors agree that this article remains permanently open access under the terms of the Creative Commons Attribution License 4.0 International License

\begin{abstract}
There is the dearth of empirical evidence on the relationship between corporate tax, aggregate federally collected tax revenues and economic growth, predominantly in the post-electronic tax era. This study seeks to assess whether corporate taxes affects aggregate federally collected tax revenues and economic growth using quarterly time-series data as extracted from the official websites of the Federal Inland Revenue Service, National Bureau of Statistics (NBS) and Central Bank of Nigeria (CBN) Statistical Bulletin covering during the period 2015q1-2020q1. The Multivariate Vector Auto Regression result revealed that corporate taxes positively and significantly affect aggregate federally collected tax revenue; company income tax (CIT) and economic growth (RGDP) were statistically significant while petroleum profit tax (PPT) is statistically insignificant to economic growth (RGDP). In view of this result, it is recommended that the Nigerian government should diversify measures aimed at jettisoning leakages in the administration of corporate tax, particularly petroleum profit and company income taxes since they contribute significantly to the revenue base of the country. Moreover, more measures that are stringent should be put in place to revitalize and fully automate the tax systems for improved revenue generation. The study is limited to the post-electronic tax system payment in Nigeria which was occasioned by tremendous improvements in the tax administration system in the
\end{abstract}

Country.

Keywords Tax Revenue, Corporate Tax, Aggregate Federally Collected Tax Revenue, Economic Growth, Petroleum Profit Tax, Company Income Tax, Finance Act 2019

\section{Introduction}

Tax refers to a mandatory levy on citizens or entities (otherwise referred to as taxpayers) by the government. The compulsory nature of the tax as noted by Ojong, Ogar and Arikpo [34], has its origin from the Biblical injunction - 'render unto Caesar the things which are for Caesar and to God, the things that are for God. Thus, tax became a mandatory levy on taxpayers regardless of their religion and social status. Taxis one of the most fundamental sources of revenue to most developed nations (Salome, Ibanichuka\&Akani [52]; Ngerebo\&Masa, [51]); however, this has not been the case for developing nation like Nigeria. Tax is one of the most obligatory levies accessible to governments to stimulate economic and social development strategies. Supporting this view, Abata [49] opines that tax is an avenue through which government finances its growth activities and these taxes 
could take the form of direct or indirect, irrespective of the means of collection. This paper focused on direct tax, specifically company income (CIT) and petroleum profit (PPT) taxes, levied on the incomes of businesses and paid directly to the relevant tax authority. Indirect and direct taxes form the basis for federally collected tax revenue (FCTR) (Oluyombo\&Olayinka, [50]).

Nwokoye and Rolle [29] opined that most nations of the world are faced with the impasse between raising internally generated revenue via taxes and investing in a friendly climate. In Nigeria, the corporation pays provisional tax not later than three (3) months from the beginning of each year of assessment, and this amount is equal to the tax paid in the prior year of assessment. The Finance Act [15], provides that the CIT rate is $30 \%$ for large companies; $0 \%$ for small; and $20 \%$ for medium companies while $2 \%$ education tax on profits. Similarly, PPT is imposed on the incomes of companies in the petroleum operations. In Nigeria, the PPT rate is 50\% chargeable on profits of petroleum operators under production sharing contracts (PSC), 65.75\% for non-PSC operators and $85 \%$ chargeable on profits of non-PSC operators after the first 5years. In Nigeria, due to the feeble contributions of tax revenue to federally collected tax revenue, the Federal Inland Revenue Service (FIRS) in conjunction with the Nigerian Inter-Bank Settlement System (NIBSS) introduced electronic tax payment in 2015 [28,39,53]. According to Okunowo [36], e-tax was initiated to increase government revenue generation among others needed to boost economic growth.

According to the Organisation for Economic Cooperation and Development (OECD, [54]), the ratio of tax to gross domestic product (GDP) in 2017 for Nigeria is about $5.7 \%$. Nigeria recorded the lowest compared to other African nations such as Ghana (14.1\%), Botswana (12.2\%), Tunisia (31.2\%), Togo (21.0\%), Egypt (17.1\%), Mali (16.7\%), Senegal (16.2\%), Rwanda (15.0\%), Kenya (18.2\%), and South Africa (28.2\%) among others. Besides, Oboh, Chinonyelum and Edeme [30], argued that the growth performance of developing nations suggests a ratio of 15-20 percent of tax revenue-GDP, an acceptable minimum threshold for developing nations. Unfortunately, some of the Economic Community of West Africa States (ECOWAS) has failed to meet this threshold using broad-based revenue sources like PPT and CIT.

Prior studies suggest that corporate taxes have not bequeathed significantly toward federally collected tax revenue and economic growth when evaluated with a tax-to-GDP ratio of other African nations [3,27]. Moreover, other studies showed that corporate taxes contribute significantly to Nigerian federally collected tax revenue and economic growth [47,34,46]; perhaps, resulting in mixed findings in tax literature particularly in the Nigerian context. Consequently, this paper assessed two indices of electronic corporate taxes (PPT and CIT) and their effects on federally collected tax revenue and economic growth, particularly during post-e-tax era. The remaining part of this paper is sectioned as follows: a review of related literature, methods, results, discussion and conclusion and recommendations.

\section{Literature Review}

\subsection{Company Income Tax (CIT) in Nigeria}

In Nigeria, CIT was initiated as far back as 1961 and has undergone tremendous amendments. These amendments involve the CIT Act of 2004 (CITA CAP C21 2004 LFN amended in 2007) and most recently, the introduction of the Finance Act of 2019, which modifies certain sections of CITA. In the Finance Act of 2019, certain subsections were deleted while new subsections inserted, particularly in areas of company dividends paid (out of retained earnings and profits), franked investments incomes, and updating table of tax exemption on interest on foreign loans among others (Finance Act [15]). Nigerian companies are registered and established under the Company and Allied Matters Act (CAMA) or any legislation like Corporate Affairs Commission (CAC). CAMA sees foreign companies as those incorporated somewhere else than in Nigeria for business operations.

Kwaji and Ishaya [25] noted that CAMA only defines CIT for the object of identifying and complying with the mandatory incorporating procedures before embarking on trade in Nigeria and also, to benefit from exemption from registration. Nigerian companies pay corporate tax to the Federal Inland Revenue Service (FIRS), irrespective of their residence. Corporate taxes are paid based on the amount of profits realised and it is assessed on total profits in pursuance to audited accounts, which are subjected to adjustments. Nigeria metamorphosed to electronic corporate tax in 2015, since the manual tax system has been so wearisome ranging from technicality, time-consuming and many other issues. Madugba, Ekwe and Kalu [27] asserted that untrained, inept tax personnel and fraudulent activities of tax authorities also pose greater contests to revenue generation, as tax regulators most times, forge receipts, thus averting government revenue into their pockets. Edewusi and Ajayi [9] opined that revenue made via CIT channels has been disappointing over time as companies evade the process because they identify the tax to be perceptive. CIT recognises any profits/gains of any corporation accruing in, consequential from, transported into, earned in or received in Nigeria, which is assessable to tax under CIT (Ekeocha, Ekeocha, Malaolu\&Oduh [12]), and are not qualified to be taxed as capital gains tax, PPT and personal income (PIT) tax acts (Finance Act [15]).

According to Finance Act [15], all companies shall have a tax identification number (TIN) and a prerequisite for the continued operations of their bank accounts. The 
CIT rate is $30 \%$ for large companies (with gross turnover of more than a N100million), $0 \%$ for small (with gross turnover of $\$ 25$ million or less), $20 \%$ for medium companies (with gross turnover more than $\$ 25$ million and less than $\$ 100$ million). These companies (large, medium or small-sized) are assessed on a preceding year basis while $2 \%$ education tax is assessed on profits and usually treated as allowable expense (Federal Inland Revenue Service [14], Finance Act, [15]). The National Bureau of Statistics (2019), maintained that revenue from CIT as a share of GDP is low, at $0.8 \%, 1.1 \%$ and $1.2 \%$ in periods 2000-2002, 2007-2009, and 2014-2018 respectively. In the first quarter of 2020, CIT as a share of GDP declined further, perhaps due to the COVID19 pandemic, which restricts business and economic activities of most corporations in Nigeria, and that of the world globally. In tax literature in Nigeria, researchers have had diverse viewpoints that CIT does not capture the majority of Nigeria's populace and as such does not meet the target of the government.

A study by Inimino, Abuo and Bosco [20] showed that if good old tests of equity, certainty, convenience and administrative efficiency are applied, Nigeria will score low considering the poor monitoring of taxpayers in the self-employed and the rate of evasion is high in unquoted private. Prior studies (Egwaikhide [11], Nwokoye\&Rolle[29]); also have disclosed that the CIT rate is so high that it creates the investment disincentive effect and erodes private the investment profits. For instance, Nwokoye and Rolle [29], observed that investment level represents less than $10 \%$ of gross domestic product (GDP) in Nigeria. More so, Egwaikhide [11] notes that a decline in the CIT rate to $20 \%$ will augment tax compliance, investment and economic growth in Nigeria. Moreover, this paper assessed electronic corporate tax (CIT) in the periods in which the country metamorphosed to e-tax to assess whether after its transitioned to e-tax, government revenue and economic growth have increased within these periods.

\subsection{Petroleum Profit Tax (PPT) in Nigeria}

The focal area of PPT in this study is the upstream sector of the petroleum industry, in that it covers oil exploration, prospecting, development and production (EPDP). Noteworthy is the fact that the Finance Act [15] modifies certain sections of PPT by way of deleting and inserting new subsections, predominantly in aspects pension contribution and use of the expression, 'Board with 'Service' in PPT administration. In 2009, PPT engrossed $85 \%$ tax rate on export and $65.75 \%$ on domestic sale of oil and gas. Ogbonna and Appah [33] posited that between the years 2000 to 2009 , the price of crude oil has contributed about $80 \%$ of the country's GDP since it rose from $\$ 13$ per barrel to $\$ 125$ per barrel. Thus, oil has become the most vital basis of government revenue, accounting for about 90 percent of total export trade (Okoro [37]); 80\% of government total revenue collected (Guage [55]) and generating more than $40 \%$ of GDP which provides $95 \%$ foreign exchange earnings and $65 \%$ of government budgetary revenues (Success, Success \&Ifurueze [56]).

The major investors in the petroleum industry are the International Oil Companies (IOCs) (Anugwom [7]). The petroleum industry has been the leading donor of government revenue in Nigeria. Economic growth may be formed through four vital dynamics - human resource, natural resource, capital formation and technological development. According to Okwara and Amori [38], taxes obtained, as revenue from other vital dynamics (human, capital formation and technological development) is incomparable to those generated from the oil sector. Usman and Adegbite [46] observed that oil companies that only market petroleum products together with those engaged in crude oil refining do not fall into the grouping of corporations in petroleum operations and are taxable under CITA. More importantly, companies engaged in both petroleum operations and marketing of their product are subjected to PPT (of their trading results from operations) while profits from marketing activities are taxable under CITA.

In Nigeria, the PPT rate varies such that $50 \%$ are chargeable from profits of petroleum operators under Production Sharing Contracts (PSC) with the Nigerian National Petroleum Corporation (NNPC) while 65.75\% for non-PSC operators (including joint ventures in the first $5 y e a r s$ during which the company has not fully amortised all pre-production capitalized expenditure). Moreover, 85\% are chargeable on the profits of non-PSC operators after the first 5years. In fact, Adegbite and Fakile [4] opined that the enormous PPT rates in Nigeria place a huge burden on petroleum companies that are yet to breakeven, especially after paying bonuses, royalties and other charges. Ilaboya and Ofiafor [19] argued that the PPT rate in Nigeria is very high compared to other African countries since these countries charges resource rent tax separately, thus reducing the PPT rate. For instance, South Africa charges $30 \%$ on PPT and $40 \%$ resource rent tax; while Uganda $30 \%$ and $0-80 \%$ resource rent tax.

Studies of Uzoka and Chiedu [47], Ojong, Ogar and Arikpo [35], Usmanand Adegbite [46] established a significant link between PPT and the economic growth of Nigeria; contrarily, a study by Abomaye-Nimenibo, Michael and Friday [3] found an insignificant association between PPT and economic growth in Nigeria. Thus, there are mixed results on the impact of PPT on economic growth in Nigeria. The mixed result may be connected with the fact that prior studies assessed both pre and post-periods of e-tax simultaneously; hence could not justify whether the pre or post-periods of e-tax influences economic growth independently. Consequently, this paper assessed electronic corporate tax (PPT) in periods of 
post-e-tax to determine if PPT significantly predisposed economic growth in Nigeria.

\subsection{Federally Collected Tax Revenues in Nigeria}

Federally collected revenue refers to the amount of money the government generates within a fiscal year (January 1 to December 31). The International Accounting Standard (IAS 18) maintains that revenue is the gross inflow of economic benefits derived in course of usual activities of an entity in a particular period. Karimi, Kimani and Kinyua [25] observed that revenue collection relates to government agency's actions to generate remarkable financial obligations from the public. In addition, the collected revenues show the financial reputation of a nation (Nwekeaku [28]). In the wake of Nigeria returning to democratic rule, it envisaged the essence of expanding its revenue base in order to hedge the economy against any ugly incidence of oil market instability, dearth of infrastructure, rising unemployment and poverty (Oriakhi\&Ahuru [42]). One fundamental means via which government seeks to achieve this is by raising taxes, particularly corporation taxes.

Akinleye, Olaoye and Ogunmakin [5] contended that tax revenue does not only make up the main revenue generation of a government but is in fact a vital part of government efforts to develop societies, economies and the nation. Nigeria's revenue profile consists mainly of oil and gas and the non-oil sectors; the oil and gas sector contributes over $70 \%$ of the federally collected tax revenue while non-oil sector, the remaining $30 \%$. Oyedele [44] claimed that despite the enormous federally collected tax revenues in Nigeria, the nation has made insignificant economic progress due to its poor approach and prevailing harsh economic condition. Federally collected tax revenues are generated via enclosed machinery established by FIRS for the administration and collection of taxes. The federally collected tax revenues (FCTR) are made up of oil and non-oil taxes, which according to Odusola [31], emanate from PIT, CIT, PPT, value-added (VAT), education, capital gains, customs and excise, minerals and mining and stamp duties taxes.

FCTR has continued to increase after the democratic era; it rose from $\$ 949,187$ million in 1999 to $\$ 7$, $303,671.55$ billion in 2010 and $\$ 11,271,290$ billion in 2014. In e-tax era, FCTR grew significantly from $\$ 16,053,763.48$ billion in 2015 to $\$ 69,799,941.95$ in 2018 and later declined to $\$ 7,0724,098.16$ billion in 2019 . Uzoka and Chiedu [47] noted that tax revenues contribute the highest revenue share to federally collected revenue of the Nigerian government; however, using FCTR as a source of financing economic activities in the country has been a cumbersome issue predominantly due to the diverse forms of resistance, which ranges from tax evasion, avoidance and corruption.

Onaolapo, Aworemi and Ajala [41] remarked that value-added, petroleum profit, company income and education taxes had $0.942 \%$ on FCTR in Nigeria; impliedly, this predicts $94.2 \%$ of the variation in FCTR. Okoli and Afolayan [35]; maintained thatVAT and PPT revenue contributes significantly to FCTR and economic growth while Madugba [27] shows that CIT has negatively contributed to FCTR and economic growth; a clear indication of mixed results in the contexts of FCTR and economic growth in Nigeria. Thus, we assessed two components of FCTR (PPT and CIT) found to produce mixed results in order to resolve the puzzle in the tax literature, particularly during the post-e-tax era in Nigeria.

\subsection{Economic Growth}

Economic growth portrays a measure of aggregate economic advancement at a national level. Egbunike, Emudainohwo and Gunardi [10], asserted that economic growth is influenced by macroeconomic policies like taxation, consumption and investment among others. Practically, all countries across the globe make every effort to augment the revenue base in order to advance economic growth as denoted by real Gross Domestic Product (RGDP).IMF (2015), OECD (2015), Ironkwe, and Agu [21] documented that RGDP defines an aggregate measure of production, which equals the sum of gross value added of all resident and institutional units engaged in production, and it aggregate the monetary value of finished goods and services procured by the final users over a period of time (quarterly or yearly).

Ali, Ali and Mohamed [6] noted that not all industrious operations are embedded in the determination of RGDP and as such, unpaid black-market operations are not since they are unreliable and burdensome to measure accurately. Hence, measurements of RGDP only counts on outputs generated within the confine of a nation for sale in the market and encompass some non-market production (e.g. defence or education services) provided by the government. Okonkwo and Chukwu [36] cited in the Central Bank of Nigeria (2016) maintained that the oil and gas sector contributes about $77.5 \%$ to economic growth while the non-oil sector generated only $22.5 \%$ in 2016 , and it can be articulated that tax and non-tax revenue sources are not too little in Nigeria.

Noteworthy is the fact that economic growth depends largely on the ability of government to generate adequate revenues to effectively provides some infrastructural facilities to suit the needs of its citizens and takes its position among nations of the world. One of the reasons why government expenditures are thought to influence economic growth negatively is due to the distortion effects of taxation. Oboh [30] contended that the association between tax revenue and economic growth has opened up a debate among policymakers for a long time and diverse literature has depicted that allocation of tax funds in an economy is dependent on fiscal policies, which often 
create behavioral misrepresentations among economic agents. Abdul-Rahamoh, Taiwo and Adejare [1], divulged that the Nigerian situation is heavily dependent on revenue generated through petroleum products, since it accounts largely the entirety government revenue. Uzoka [47] maintained that economic growth of any nation is measure on the amount of revenue generated; one vital way of generating revenue is via tax. Oyebisi [43] affirmed that from 1994 to 2013, trends in Nigeria's RGDP recorded a steady increase from $\$ 345$ billion to \#950 billion while in the pre-tax era, it increased from $\$ 690$ billion to $\$ 707$ billion.

This is a clear indication that the Nigerian economy has experienced steady growth, which could be ascribed to increased tax receipts by the Nigerian government in the form of company, petroleum profit, value added, customs and excise duties and many other revenue tax sources. Our study adopts the measurement of the economic growth (RGDP) as used in prior studies done by Jones, Ihendinihu and Nwaiwu [23]; Ayeni, Ibrahim and Adeyemi [8]; Jones, Nwawuru and Nmesirionye [24]; Inimino, Abuo and Bosco [20]. Corporate taxes bring about substantial revenue to the government and have bearing on RGDP, which is the standard indicator for measuring the economic wellbeing of a nation.

\subsection{Corporate Tax, Aggregate Federally Collected Tax Revenues and Economic Growth: Post Electronic Tax Era}

In accordance with the payment and settlement system of vision 2020 and expedition of Section 47 of the Central Bank Act (CBN) of 2007, the Federal Government of Nigeria issued a guideline mandating all federal taxes to be collected electronically before the end of 2009. Even with the issuance of this guideline, they were some unexpected deviances in compliance probably because of the technicality of the method or lack of proper education in handling its system. Remarkably, Federal Inland Revenue Service (FIRS) in juxtaposition with the Nigerian Inter-Bank Settlement System (NIBSS) introduced electronic tax payment in 2015 [28,39,53]. Electronic taxation is the automation of all tax processes from tax registration, assessment and filing of returns, payment of taxes, and obtaining receipts. Taxation in Nigeria is now a function of Information Communication Technology (ICT) with the aim of the increased revenue base of the nation and enhancing economic growth.

Newman [59] purported that as of 29 June of 2017, the Federal Inland Service (FIRS) reorganized the electronic tax system to operate nationwide by inculcating six (6) new tax modules which include; e-registration, e-stamp duty, e-tax payment, e-receipt, e-filing and, electronic tax clearance certificates. Uzoka, and Chiedu [47] noted that in Nigeria, tax revenue contributes the highest revenue share to the federal government, and using this efficient and voluntary compliance method will bring improvements in an array of indicators such as literacy rates, life expectancy, and poverty rate because whenever economic wellbeing is mentioned, attention is usually drawn to the gross domestic product as a specific measure of economic welfare. Therefore, the post electronic era is expected to increase federally collected revenues such that it has a way of reducing tax evasion and which it promotes stable economic growth [50,53] while other researchers have a divergent opinion and see a negative impact in adopting electronic tax; these are evident in the studies of [32,39].

\section{Theoretical Underpinning}

This paper employs the Faculty Theory or Ability-to-Pay Theory (APT) as its theoretical underpinning. APT was developed by Adam and Pigou (1903); however, modified and later called equality of sacrifice or faculty theory. APT is a principle, which requires that collected taxes be distributed among individual taxpayers according to their capacity, taking into cognizance, all relevant individual taxpayers' characteristics. In the views of Worlu and Nkoro[48], taxpayers' capacity to pay tax in order to boost the revenue base of government and in turn economic growth depends on one dynamic, which is probably the availability of infrastructure. The APT theory suggests that taxpayers whether persons or corporations should pay tax with gaze-at to the profits or gains generated from their trade, business or economic activities. Perhaps, one among the reasons for diverse tax rates for different tax sources in most nations of the world.

Generally, it is assumed that an efficient tax system, which contributes to the government revenue base, would accomplish laudable projects, aid economic stabilization, and in turn augment economic growth. Abiola and Asiweh [2] maintained that most policy changes are without adequate consideration of taxpayers coupled with the administrative arrangement, which has in no small measure, stalled the effective and efficient implementation and goal congruence of Nigerian's tax system. According to Adegbite and Fakile [4], this places a huge burden on corporations that are yet to break even in their industries. Most corporations usually avoid and/ or evade taxes and thus degenerate government revenues, which in turn hampers economic growth.

\section{Methodology}

In examining electronic corporate taxes as they affect federally collected tax revenue and economic growth, this paper employed electronic corporate tax measures of PPT, CIT, FCTR and economic growth (measured by Real Gross Domestic Product -RGDP). PPT, CIT and FCTR 
were obtained from the Federal Inland Revenue Service (FIRS) and National Bureau of Statistics (NBS) databases while RGDP data from the Central Bank of Nigeria (CBN) statistical bulletin. The paper analysed quarterly time-series data covering the period 2015q1-2020q1.

The choice of this timeframe is premised on the fact that it encapsulates the commencement of electronic-tax payment system by the FIRS in conjunction with the Nigeria Inter-Bank Settlement System (NIBSS) ([32,39]). Our empirical model is adapted from studies of Kwaji and Ishaya [26] and Olusegun [40] and restricted to incorporate electronic tax on FCTRand RGDP. The dependent variables are FCTR and RGDP while the independent variables are PPT and CIT. A Multivariate Vector Auto-Regressive (VAR) model was used to gauge the effects of PPT and CIT on FCTR and RGDP. VAR model is expressed as:

$$
\begin{aligned}
& \mathrm{Y} 1_{\mathrm{t}}=\alpha_{11} \mathrm{Y} 1_{\mathrm{t}-1}+\alpha_{12} \mathrm{Y} 2_{\mathrm{t}-1}+\varepsilon 1_{\mathrm{t}} \\
& \mathrm{Y} 2_{\mathrm{t}}=\alpha_{21} \mathrm{Y} 1_{\mathrm{t}-1}+\alpha_{22} \mathrm{Y} 2_{\mathrm{t}-1}+\varepsilon 2_{\mathrm{t}}
\end{aligned}
$$

In order to capture the variables of the study, equations 3-4 are represented in the explicit VAR forms as:

$$
\mathrm{K} \quad \mathrm{k} \quad \mathrm{k}
$$

$\mathrm{FCTR}_{\mathrm{t}}=\alpha_{11}+\Sigma \alpha_{11} \mathrm{PPT}_{\mathrm{t}-\mathrm{j}}+\Sigma \alpha_{12} \mathrm{CIT}_{\mathrm{t}-\mathrm{j}}+\Sigma \mathrm{b}_{13} \mathrm{FCTR}_{\mathrm{t}-\mathrm{j}}+\varepsilon_{\mathrm{t}}$

$$
\begin{aligned}
& \mathrm{j}=1 \quad \begin{array}{ccc}
\mathrm{j}=1 \\
\mathrm{k} & \mathrm{kk}
\end{array} \\
& \mathrm{RGDP}_{\mathrm{t}}=\alpha_{21}+\Sigma \alpha_{21} \mathrm{PPT}_{\mathrm{t}-\mathrm{j}}+\Sigma \alpha_{22} \mathrm{CIT}_{\mathrm{t}-\mathrm{j}}+ \\
& j=1 \quad j=1 \quad j=1
\end{aligned}
$$

Noteworthy is the fact that six (6) observations are sufficient for quarterly time-series data when there is no randomness in the data series (Hyndman \&Andrey [18]). Moreover, when the probability value of the run-test of randomness is greater than the predetermined significance level, we accept the null hypothesis and otherwise, reject it. Besides a major problem with time-series data is that they usually exhibit time characteristics (non-stationarity) which perhaps may lead to spurious regression outcomes and thus, make statistical inferences void. Another outcome is the view of Johansen [22] is that the variables are not co-integrated. To establish the integration of variables, we employed the Augmented Dickey-Fuller (ADF) and Phillip-Perron (PP) unit root test. All tests are based on series in equations 5-6

$$
\begin{gathered}
\Delta y_{t}=\alpha y_{t}-1+\sum \beta y_{t-1}+\delta y t+\varepsilon_{t} \text { (for levels) (eq. 5) } \\
i=1 \\
m \\
\Delta \Delta y_{t}=\alpha \Delta y_{t}-1+\sum \beta \Delta y_{t-1}+\delta y t+\varepsilon_{t} \text { (for first difference) } \\
-\quad(\text { eq. } 6) \\
i=1
\end{gathered}
$$

$\Delta \mathrm{y}$ is the first difference of series, $m$ is a number of lags and $t$ is time. Given a variable $Y$, for instance, the following estimation is used:

$$
\Delta y_{t}=\alpha_{0}+y_{t-1}+\sum_{i=1}^{\mathrm{m}} \alpha_{t-1}+\varepsilon_{t} \quad(t=1, \ldots \ldots, n)(\text { eq.7) }
$$

$\Delta$ is the first difference operator, $\alpha$ constant parameters and $\varepsilon_{t}$ is stationary stochastic process. To determine the order of integration of series, equation 7 is modified to capture the second difference on lagged first and $n$ lags of second difference as follows:

$$
\left.\Delta \mathrm{y}_{\mathrm{t}}=\mu_{1} \Delta_{\mathrm{t}-1}+\partial_{\mathrm{t}} \Delta^{2} \mathrm{Y}_{\mathrm{t}-1}+\varepsilon_{\mathrm{it}} \quad(\mathrm{i}=1), \ldots, \mathrm{n}\right)(\text { eq. 8) }
$$

$\mu$ and $\partial$ are constant parameters. The $n$ lagged difference terms are captured so that the error term $\varepsilon_{t}$ and $\varepsilon_{i t}$ in both equations are serially independent. A stationary time series is said to be integrated of order zero or $1(0)$, and a time series $Y_{t}$ is defined to be integrated of order one or 1(1) if $\Delta y_{t}$ is a stationary time series (Gujarati, 2003). Also, we conducted a Granger causality test to estimate the short-run link between corporate tax indices and federally collected tax revenue and economic growth; the statistical analysis was done via STATA 13.0. 
Table 1. Summary Statistics for Quarterly Corporate Tax Indices (PPT and CIT), Federally Collected Tax Revenue (FCTR) and Real Gross Domestic Product (GDP)

\begin{tabular}{|ccccc|}
\hline & PPT & CIT & FCTR & RGDP \\
\hline Mean & 423.3895 & 317.96 & 1058.624 & 62480.50 \\
Median & 390.7 & 305.4 & 1046.89 & 57071.04 \\
Maximum & 672.57 & 513.38 & 1564.57 & 110856.9 \\
Minimum & 136.57 & 152.42 & 563.87 & 32954.55 \\
Std. Dev. & 151.9406 & 115.8825 & 277.4351 & 23580.40 \\
Skewness & -.0687029 & .2254197 & -.0200085 & .7180794 \\
Kurtosis & 2.063752 & 2.082114 & 2.092243 & 2.450458 \\
Jarque-Bera & 0.49100 & 2.53200 & 0.60300 & 1.70400 \\
Probability & 0.78233 & 0.28119 & 0.73966 & 0.42653 \\
Observations & 21 & 21 & 21 & 21 \\
Sum & 8891 & 6677 & 222231 & 1312091 \\
\hline
\end{tabular}

Source: Researchers Computation via STATA 13.0

\section{Data Analysis and Results}

From Table 1, we can see that none of the corporate tax indices (PPT\& CIT), FCTR, and RGDP variables exhibited negative average values. This is expected, given the characteristics of the periods covered and the impact of electronic tax administration, which occurred in 2015. Quarterly standard deviations range from $1.16 \%$ (CIT) to $235.8 \%$ (RGDP). PPT varied $1.52 \%$ while FCTR $2.77 \%$.All data series (PPT, CIT, FCTR and RGDP) displayed non-zero skewness; also, variables of CIT and RGDP skewed to the right while PPT, and FCTR skewed to the left as indicated by their positive and negative values respectively. All the variables have a normal distribution as indicated by the kurtosis value, which is closer to three (3). Jarque-Berra statistics are insignificant at $5 \%$ level based on their corresponding probability values, suggesting that all the variables of the study are normally distributed. To ensure that there is no randomness in the data series, a run test of randomness was done.

Table 2. Run-Test of Randomness of Data Series

\begin{tabular}{|ccccc|}
\hline & PPT & CIT & FCTR & RGDP \\
\hline z-test & 0.16 & 0.11 & 1.23 & 0.12 \\
Probability & 0.87 & 0.91 & 0.22 & 0.90 \\
Observations & 21 & 21 & 21 & 21 \\
\hline
\end{tabular}

Source: Researchers Computation via STATA 13.0

The run-test of data randomness series (Table 2) implies that we accept the null hypothesis of no randomness since the probability values of run-tests are greater than the significance level $(0.05 \%)$.Prior to assessing the conditional variance, it is practical to test for unit roots in the series using Augmented Dickey-Fuller(ADF) and Phillips-Perron (PP) tests.
Table 3. Unit Root Tests

\begin{tabular}{|ccc|}
\hline Variables & ADF Test in Level & PP Test in Level \\
\hline PPT & -1.579 & -1.493 \\
CIT & $-5.885^{* * *}$ & $-5.471 * * *$ \\
FCTR & -2.390 & -2.385 \\
RGDP & $-5.646^{* * *}$ & $-5.441^{* * *}$ \\
\hline
\end{tabular}

Source: Researchers Computation via STATA 13.0*, **, *** denote rejection of null hypothesis @10\%,5\%,\& 1\% levels respectively.

The ADF unit root test indicates that corporate tax (CIT) and RGDP series are integrated of order one, except for PPT and FCTR. The Phillips-Perron test reaches similar decisions for CIT and RGDP (10\% level)). Alternatively, PPT and FCTR series do not have unit roots based on the $\mathrm{ADF}$ and PP tests (all at $1 \%$ level).

Table 4. Correlation Matrix

\begin{tabular}{|ccccc|}
\hline & PPT & CIT & FCTR & RGDP \\
\hline PPT & 1.0000 & & & \\
CIT & 0.2303 & 1.0000 & & \\
FCTR & .67290 & 0.4136 & 1.0000 & \\
RGDP & -0.2572 & -0.6889 & -0.6290 & 1.0000 \\
\hline
\end{tabular}

Source: Researchers Computation via STATA 13.0

Table 4 shows the correlation matrix for corporate tax indices (PPT\&CIT) and FCTR and RGDP. Correlations with PPT and CIT are positive, indicating that during the studied period, corporate tax moved together with FCTR and RGDP. The highest correlation (.6889) is between CIT and RGDP; however did not exceed the maximum benchmark of 0.8 , suggesting the absence of multicollinearity among the studied variables. 
Table 5. Results of the Granger Causality Tests (P-Values)

\begin{tabular}{|ccc|}
\hline Null Hypothesis & $\begin{array}{c}\text { PPT/CIT to } \\
\text { FCTR/RGDP }\end{array}$ & $\begin{array}{c}\text { FCTR/RGDP } \\
\text { to PPT/CIT }\end{array}$ \\
\hline $\begin{array}{c}\text { PPT/CIT does not granger } \\
\text { cause FCTR/RGDP }\end{array}$ & 0.0650 & 0.2980 \\
$\begin{array}{c}\text { FCTR/RGDP does not granger } \\
\text { cause PPT/CIT }\end{array}$ & 0.1178 & 0.1194 \\
\hline
\end{tabular}

Source: Researchers Computation via STATA 13.0

The results in Table 5 reveal that in the short-run corporate tax indices (PPT\&CIT) Granger-cause variations in FCTR and RGDP in a directional manner, particularly during the post-e-tax periods. Impliedly, as Nigerian corporate tax indices (PPT\& CIT) changes, it can increase FCTR and RGDP.

Presented in Table 6 is the result of multivariate VAR of quarterly time-series data involving electronic corporate taxes indices (PPT and CIT), federally collected tax revenue (FCTR) and economic growth (RGDP). The Akaike Information Criterion (AIC) and Bayesian Information Criterion (BIC) were used to compare the maximum likelihood models. The Electronic corporate tax model (PIT and CIT) has AIC and BIC values of 31.38354 and 32.07944 respectively; thus, AIC has a smaller value than $\mathrm{BIC}$, indicating that $\mathrm{AIC}$ best fits the time-series data.

Besides, multivariate VAR results showed that $\mathrm{R}^{2}$ is 0.9911 and 0.8735 for FCTR and RGDP, indicating that corporate tax indices (PPT and CIT) explained about 99.1\% and $87.4 \%$ of the systematic variation in FCTR and RGD prospectively. Moreover, an examination of the Wald Chi2 suggests that both FCTR and RGDP explains the short-run changes at $\mathrm{P}<0.0000$. The coefficients of corporate tax indices (PPT and CIT) and FCTR were statistically significant and carrying the right sign (positive). Impliedly, electronic corporate tax positively and significantly affects federally collected tax revenue (FCTR) in Nigeria during the post-e-tax period. On the other hand, the coefficient of corporate tax index (CIT) and RGDP was statistically significant while PPT is statistically insignificant. Moreover, both corporate tax indices (PPT and CIT) are carrying negative signs; an indication that while CIT statistically and negatively affects economic growth (RGDP), PPT negatively and insignificantly affects economic growth (RGDP) in Nigeria during the post-e-tax period.

Table 6. Results of the Multivariate VAR

\begin{tabular}{|c|c|c|c|c|c|}
\hline \multicolumn{4}{|c|}{$\begin{array}{c}\text { Log likelihood=-284.1346 } \\
\text { FPE = }=1.57011 \\
\text { Det }(\text { Sigma_m1 })=3.35010\end{array}$} & \multicolumn{2}{|c|}{$\begin{array}{l}\mathrm{AIC}=31.38354 \\
\mathrm{HQIC}= \\
\mathrm{BIC}=31.50131 \\
\end{array}$} \\
\hline Equation & Parms & RMSE & R-sq & Chi2 & $\mathrm{P}>$ chi 2 \\
\hline FCTR & 7 & 30.2645 & 0.9911 & 211.7740 & 0.0000 \\
\hline \multirow[t]{2}{*}{ RGDP } & 7 & 645.99 & 0.8735 & 131.2519 & 0.0000 \\
\hline & & Coefficient & Std. Error & $\mathbf{z}$ & $\mathbf{p}>/ \mathbf{z} /$ \\
\hline \multirow[t]{2}{*}{ FCTR } & $\begin{array}{l}\text { FCTR } \\
\text { L1 } \\
\text { L2 }\end{array}$ & $\begin{array}{l}-.0130269 \\
-.0023191\end{array}$ & $\begin{array}{l}.0418965 \\
.0343667\end{array}$ & $\begin{array}{l}-0.31 \\
-0.07\end{array}$ & $\begin{array}{l}0.756 \\
0.946\end{array}$ \\
\hline & $\begin{array}{l}\text { RGDP } \\
\text { L1 } \\
\text { L2 } \\
\text { PPT } \\
\text { CIT } \\
\text { Cons }\end{array}$ & $\begin{array}{c}-.0001782 \\
.0006662 \\
1.215647 \\
1.245421 \\
151.7155\end{array}$ & $\begin{array}{l}.0003319 \\
.0003315 \\
.0706114 \\
.0657211 \\
58.68055\end{array}$ & $\begin{array}{c}-0.54 \\
2.01 \\
17.22 \\
18.95 \\
2.59\end{array}$ & $\begin{array}{l}0.591 \\
0.044 \\
0.000 \\
0.000 \\
0.010\end{array}$ \\
\hline \multirow[t]{7}{*}{ RGDP } & $\begin{array}{l}\text { FCTR } \\
\text { LI } \\
\text { L2 }\end{array}$ & $\begin{array}{l}5.609556 \\
1.181341\end{array}$ & $\begin{array}{l}13.35334 \\
10.95342\end{array}$ & $\begin{array}{l}-0.42 \\
-0.11\end{array}$ & $\begin{array}{l}0.674 \\
0.914\end{array}$ \\
\hline & RGDP & & & & \\
\hline & LI & .016927 & .1057876 & 0.16 & 0.873 \\
\hline & L2 & -.0791207 & .1056721 & -0.75 & 0.454 \\
\hline & PPT & -19.42911 & 22.50542 & -0.86 & 0.388 \\
\hline & CIT & -180.0545 & 20.94677 & -8.60 & 0.000 \\
\hline & Cons & 124353 & 18702.8 & 6.65 & 0.000 \\
\hline
\end{tabular}

Source: Researchers Computation via STATA 13.0 


\section{Discussion}

Fundamentally, the interest of any nation is to improve its revenue base to match expenditure and provide public goods and social amenities for the welfare of citizens. In Nigeria, successive governments have made concerted efforts towards augmenting revenue base either via investments, taxation, engaging in domestic or foreign borrowings. Tax instrument has been deemed as one of the vital means of realizing government objectives, since it does not attracts interest like those of domestic of foreign borrowings. In fact, the debate in tax literature is whether corporate taxes, particularly PPT and CIT contribute to the level of federally collected tax revenue and promote economic growth. This debate stems from mixed results on the nexus between corporation taxes, federally collected tax revenues and economic growth in Nigeria ([47], [3], [43], [47], [27]). The mixed findings could be attributable to the fact that prior studies failed to assess independently, the post-e-tax effects of corporation taxes on federally collected tax revenues and economic growth.

The post-e-tax eras has witnessed some fundamental improvements in tax administration system, coupled with the amendments made to Nigerian tax law (Finance Act of 2019), which affects corporation taxes. However, whether the result of prior studies still holds in post e-tax era, is an issue that has not been established in the literature, particularly in Nigeria; First, finding shows that in the short-run, corporate tax (PPT\&CIT) granger-cause variations in federally collected tax revenue and economic growth in a directional manner in the period investigated. The finding disagrees in part with studies conducted by Usman and Adegbite [46], Gopar [16], that petroleum profit tax does not granger-cause economic growth and corresponds to the study done by Charles, Ekwe and Azubike [57] that petroleum profit tax granger-cause federally collected tax revenues and economic growth. The mixed finding is perhaps due to diverse periods assessed by these sets of studies.

Again, that company income tax granger-cause federally collected revenues and economic growth is an issue that is yet to be established in taxation literature, particularly in the Nigeria context. Second, the VAR result showed that corporate tax indices (PPT and CIT) and federally collected tax revenue were statistically significant and positive. This implies that corporate tax positively and significantly affects federally collected tax revenue. This finding corroborates with a study done by Onaolapo, Aworemi and Ajala [41] that company income tax significantly and positively influences federally collected revenue in Nigeria.

Third, that company income tax and economic growth were statistically significant while petroleum profit tax is statistically insignificant. Moreover, the electronic corporate tax indices (PPT and CIT) are carrying negative signs; an indication that while company income tax statistically and negatively affects economic growth, petroleum profit tax negatively and insignificantly affects economic growth in Nigeria during the post-e-tax period. This finding corroborates with prior studies conducted by Uzoka and Chiedu [47]; Ojong [34]; Usman and Adegbite[46] on the part that a significant relationship exists between petroleum profit tax and economic growth.

\section{Conclusion}

This study seeks to; assess whether electronic corporate tax (PPT and CIT) affect federally collected tax revenue and economic growth in Nigeria; and ascertain if whether electronic corporate tax measures of the study granger-cause federally collected tax revenue and economic growth. Quarterly time-series data was used during the period 2015q1-2020q1. Findings indicated that electronic corporate taxes (PPT and CIT) positively and significantly affect federally collected tax revenue; while CIT and economic growth were statistically significant and PPT is statistically insignificant.

Given the study's findings, it is recommended that the Nigerian government should diverse measures aimed at jettisoning leakages in the administration of electronic corporate taxes, particularly company income tax since it contributes significantly to the revenue base of the country. Moreover, more measures that are stringent should be put in place to revitalize and fully automate the tax systems for improved revenue generation; the revenue generated can be plunged into the economy for enhanced economic growth. Further studies are needed to assess the relationship between other sources of taxes (like value-added, stamp duty, excise duty taxes etc.) on federally generated revenue and economic growth in the pos-e-tax era.

This study contributes to knowledge by filling the gap in literature on the association between electronic corporation taxes (PPT and CIT), federally collected tax revenue and economic growth in post-e-tax period in Nigeria. In addition, the study affirmed thatcompany income tax granger-cause federally collected revenue and economic growth - an issue that is yet to be established in literature in Nigeria.

\section{REFERENCES}

[1] Abdul-Rahamoh, A. O., Taiwo, H. F., \&Adejare, T. A, "The analysis of the effect of petroleum profit tax on Nigerian economy," Asian Journal of Humanities and Social Sciences, Vol. 1, No. 1, pp.: 26-37, 2013.

[2] Abiola, J. \&Asiweh, M, "Impact of tax administration on government revenue in a developing economy: A case study of Nigeria,"International Journal of Business and Social 
Science, Vol. 3, No. 9, pp.: 99-113, 2012.

[3] Abomaye-Nimenibo, W. A. S., Michael, J. E. \& Friday, H. $\mathrm{C}$, "An empirical analysis of tax revenue and economic growth in Nigeria from 1980 to 2015," Global Journal of Human-Social Science, Vol. 18, No. 3, pp.: 9-40, 2018.

[4] Adegbite, F. F., \&Fakile, A. S, "Petroleum profit tax and Nigeria economic development," International Journal of Research in Computer Application \& Management, Vol. 1, No. 1, pp.: 11-18, 2011.

[5] Akinleye, T. G., Olaoye, O. F. \&Ogunmakin, A. A, "Effect of tax identification number on revenue generation in Southwest Nigeria,"Journal of Accounting and Taxation, Vol. 11, No. 7, pp.: 170-177, 2019.https://doi.org/10.5897/JAT2019.0360

[6] Ali, A. A., Ali, Y. S. A. \& Mohamed, S. D, "The impact of tax revenues on economic growth: A time series evidence from Kenya,"Academic Research International, Vol. 9, No. 3, pp.: 163-170, 2018.

[7] Anugwom, E, "Oil minorities and the politics of resource control in Nigeria", Africa Development, Vol. 4, No. 2, pp.: 87-120, 2019.

[8] Ayeni, A. P., Ibrahim, J., \&Adeyemi, A. O, "Tax revenue and Nigerian economic growth," European Journal of Accounting, Auditing and Finance Research, Vol. 5, No. 11, pp.: 75-85, 2017.

[9] Edewusi, D. G., \&Ajayi, I. E, "The nexus between tax revenue and economic growth in Nigeria," International Journal of Applied Economics, Finance and Accounting, Vol. 4, No. 2, pp.: 45-55, 2019.https://doi.org/10.33094/8.2017.2019.42.45.55

[10] Egbunike, F. C., Emudainohwo, O. B. \&Gunardi, A, "Tax revenue and economic growth: A study of Nigeria and Ghana," Signifikan: JurnalllmuEkonomi, Vol. 7, No. 2, pp.: 213-220, 2018. https://doi.org/10.15408/sjie.v7i2.7341

[11] Egwaikhide, O. F, "Nigeria's low tax collection and poor quality of government expenditure: Political and administrative impediments to improvement," Centre for Global Development Policy Paper, pp.:162, 1-49, 2019.

[12] Ekeocha, P.C., Ekeocha, C.S., Malaolu, V. \& Oduh, M. O., "Revenue implications of Nigerian tax system," Journal of Economics and Sustainable Development, Vol. 3, No. 8, pp.: 206- 214,2012

[13] Echekoba, F. N. \& Ezu, G.K., "Electronic retail payment systems: User acceptability and payment problems in Nigeria," Arabian Journal of Business and Management Review, Vol. 1, No. 9, pp.: 111-123, 2016.https://doi.org/10.12816/0002165

[14] "Federal Inland Revenue Service" Available online at https:// www.firs.gov.ng/e-Services/e-TaxPayment, 2018. [Accessed 17 May, 2020]

[15] Finance Act, "Explanatory memorandum". Abuja: Publication of the Federal Republic of Nigeria, 2019.

[16] Gopar, K.J., Dalyop, M. L. \& Yusuf, D.B., "Impact of petroleum profits tax on economic growth in Nigeria: A longitudinal study," Tax Academy Research Journal, Vol. 1, No. 1, pp.: 139-150, 2015.
[17] Gujarati, D, "Basic Econometrics," (4th Edition), New York: McGraw-Hill Inc. 2003.

[18] Hyndman, R. J. \&Andrey, V. K, "Minimum sample size requirements for seasonal forecasting models," Foresight, Vol. 6, pp.: 12-15, 2007.

[19] Ilaboya, O. J. \&Ofiafor, E, "Petroleum profit tax and economic growth in Nigeria,"British Journal of Business and Management Research, Vol. 1, No. 2, pp.: 55-67, 2014.

[20] Inimino, E. E., Abuo, M. A. \&Bosco, I. E, "Taxation and economic growth in Nigeria,"International Journal of Research and Innovation in Social Science, Vol. 2, No. 4, pp.: 113-122, 2018.

[21] Ironkwe, U.I. \&Agu, E.O, "Tax revenue and economic development in Nigeria,"International Journal of Advanced Academic Research \& Economic Evaluation, Vol. 5, No. 4, pp.: 1-15, 2019.

[22] Johansen, S, "Statistical analysis of co-integration vectors," Journal of Economic Dynamics and Control, Vol. 12, No. 2-3, pp.: 231-254, 1988. https://doi.org/10.1016/0165-1889 (88) $90041-3$

[23] Jones, E., Ihendinihu, J. U., \& Nwaiwu, J.N, "Total revenue and economic growth in Nigeria: Empirical evidence," Journal of Emerging Trends in Economics and Management Sciences, Vol. 6, No. 1, pp.: 40-46, 2015.

[24] Jones, E., Nwawuru, C. E. \&Nmesirionye, J. A, "Effect of value added tax on economic growth in Nigeria: Empirical investigation," EPRA International Journal of Economic and Business Review, Vol. 6, No. 2, pp.: 73-81, 2018.

[25] Karimi, H., Kimani, E.M. \&Kinyua, J.M, "Effect of technology and information systems on revenue collection by the county government of Embu, Kenya," International Academic Journal of Information Systems and Technology, Vol. 2, No. 1, pp.: 19-35, 2017.

[26] Kwaji, S. F. \&Ishaya, J. D, "Empirical analysis of tax revenue collection by the federal government in Nigeria," European Journal of Accounting, Auditing and Finance Research, Vol. 5, No. 2, pp.: 1-11, 2017.

[27] Madugba, J. U., Ekwe, M. C., \&Kalu, J. M, "Corporate tax and revenue generation: Evidence from Nigeria," Journal of Emerging Trends in Economics and Management Sciences, Vol. 6, No. 5, pp.: 333-339, 2015.

[28] Nwekeaku, E. C, "Revenue enhancement and national corporate objectives in Nigeria," American Journal of Humanities and Social Sciences, Vol. 1, No. 4, pp.: 251-257, 2013. https://doi.org/10.11634/232907811301413

[29] Nwokoye, G. A. \&Rolle, R. A, "Tax reforms and investment in Nigeria: An empirical examination," International Journal of Development and Management Review, Vol. 10, pp.: 39-51, 2015.

[30] Oboh, J. O., Chinonyelum, O. J., \&Edeme, R. K, "Tax revenue and economic growth in selected ECOWAS countries, Evidence from sure model," International Journal of Academic Research in Accounting, Finance and Management Sciences, Vol. 8, No. 3, pp.: 310-324, 2018.https://doi.org/10.6007/IJARAFMS/v8-i3/4917

[31] Odusola, A, "Tax policy reforms in Nigeria," United Nations University World Institute for Development 
Economic Research, 2006.

[32] Ofurum, N.C., Amaefule, I. L., Okonya, E. B., \&Amaefule, C. H, "Impact of e-taxation on Nigeria's revenue and economic growth: A pre-post analysis," International Journal of Finance and Accounting, Vol. 7, No. 2, pp.: 19-26, 2018.

[33] Ogbonna, G. N. \&Appah, E, "Petroleum income and Nigerian economy: Empirical evidence," Arabian Journal of Business and Management Review, Vol. 1, No. 9, pp.: 33-59, 2012. https://doi.org/10.12816/0002159

[34] Ojong, M. C., Ogar, A., \&Arikpo, F.O, "The impact of tax revenue on economic growth: Evidence from Nigeria," Journal of Economics and Finance, Vol. 7, No. 1, pp.: 32-38, 2016.

[35] Okoli, N. M. \& Afolayan, S. M., "Correlation between value added tax (VAT) and National revenue in Nigeria: An ECM model," Research Journal of Finance and Accounting, Vol. 6, No. 6, pp.: 230-238, 2015.

[36] Okonkwo, I. V. \&Chukwu, K.O, "Government tax revenue and economic development in Nigeria (1996-2017)," International Journal of Research in Business, Economics and Management, Vol. 3, No. 3, pp.: 9-105, 2019.

[37] Okoro, G.E., "Oil price volatility and economic growth in Nigeria: A vector auto-regression (VAR) approach" ActaUniversitatiDanubius, Vol. 10, No. 1, pp.: 70-82, 2014.

[38] Okwara, C.C. \&Amori, O.M., "Impact of tax revenue on economic growth in Nigeria,"International Journal of Advanced Scientific Research, Vol. 2, No. 2, pp.: 90-102, 2017.

[39] Olaoye, O.C., \&Atilola, O.C, "Effect of e-tax payment on revenue generation in Nigeria,"Journal of Accounting, Business and Finance Research, Vol. 4, No. 2, pp.: 56-65, 2018. https://doi.org/10.20448/2002.42.56.65

[40] Olusegun, B.E. (2018). "Implications of economic recession for value added tax revenue: A case of Nigeria," Continental Journal of Sustainable Development, Vol. 9, No. 1, pp.: 40-53, 2018.

[41] Onaolapo, A.A., Aworemi, R.J. \& Ajala, O.A, "Assessment of value added tax and its effects on revenue generation in Nigeria," International Journal of Business and Social Science, Vol. 4, No. 1, pp.: 220-225, 2013.

[42] Oriakhi, E.D. \&Ahuru, R.R. "The impact of tax reform on federal revenue generation in Nigeria," Journal of Policy and Development Studies, Vol. 9, No. 1, pp.: 92-108, 2014.https://doi.org/10.12816/0011185

[43] Oyebisi, M.O., Oyedele, O.M., Oyeyemi, O.M. Ayodotun, S.I. \&Adebola, A. (2017). "Impact of direct and indirect tax on the Nigerian economic growth," Binus Business Review, Vol. 8, No. 3, pp.: 215- 220, 2017. https://doi.org/10.21512/bbr.v8i3.3621

[44] Oyedele, T, "Tax and fiscal policy prospects," Nigeria: PricewaterhouseCoopers, 2017.

[45] Success, M.J., Success, E.B. \&Ifurueze, K.S.M, "Impact of petroleum profit tax on economic development of Nigeria," British Journal of Economics, Finance and Management Sciences, Vol. 5, No. 2, pp.: 60-70, 2012.

[46] Usman, O.A. \&Adegbite, T.A, "The impact of petroleum profit tax on economic growth in Nigeria: The co-integration analysis," International Academic Conference, London, pp.: 540-551, 2015.

[47] Uzoka, P.U. \&Chiedu, C.O,"Effect of tax revenue on economic growth in Nigeria," International Journal of Social Sciences and Management Research, Vol. 4, No. 7, pp.: 17-24, 2018.

[48] Worlu, C.N. \&Nkoro, E, "Tax revenue and economic development in Nigeria: A macro-econometric approach," Academic Journal of Interdisciplinary Studies, Vol. 1, No. 2, pp.: 211- 223, 2012.

[49] Abata, A. M, "The Impact of Tax Revenue on Nigerian Economy: Case of Federal Board of Inland Revenue," Journal of Policy and Development Studies, 9(1) 109-121, 2014.https://doi.org/10.12816/0011186

[50] Olurankinse, F., \&Oladeji, E. O, "Self-Assessment, Electronic-Taxation Payment System and Revenue Generation in Nigeria," Accounting \& Taxation Review, Vol. 2, No. 1, pp.: 39-55, 2018.

[51] Ngerebo-A, T. A., \& Orji, G, "Tax reforms and standard of living in Nigeria," International Journal of Financial Management (IJFM), Vol. 8, No. 1, pp.:7-22, 2019.

[52] Salome, O. I., Ibanichuka, L. E., \&Akani, N. F, "A Time Series Analysis of Effect of Tax Revenue on Economic Development of Nigeria," Developing Country Studies, Vol. 6, No. 9, pp.:65-70, 2016.

[53] Alake, S. F., \&Olatunji, V. A, "Impact of Electronic Taxation on Tax Evasion and Avoidance: A Case Study of Nigerian Banks," International Journal of Current Research in Multidisciplinary, Vol. 2, No. 2, pp.:19-26, 2019.

[54] Organisation for Economic Co-operation and Development (OECD), "Rising tax revenues are key to economic development in African countries," 2017. Retrieved from: http://www.oecd.org/tax/.

[55] Guage, "How FIRS is moving up Nigeria in World Ease of Doing Business,"Quarterly Publication of the Federal Inland Revenue Service, pp.:3-45, 2018.

[56] Success, M. J., Success, E. B., \&Ifurueze, K. S. M, "Impact of Petroleum Profit Tax on Economic Development of Nigeria," British Journal of Economics, Finance and Management Sciences, Vol. 5, No. 2, pp.: 60-70, 2012.

[57] Charles, J. U., Ekwe, C. M., \&Azubike, B. U. J, "Federally Collected Tax Revenue and Economic Growth of Nigeria: A Time Series Analysis," Accounting \& Taxation Review, Vol. 2, No. 1, pp.:24-38, 2018.

[58] Newman, U. R., \&Eghosa, O. E. "Electronic taxation in Nigeria: Challenges and prospects," International Company and Commercial Law Review, Vol. 30, No.1, pp.:47-64, 2019. 